
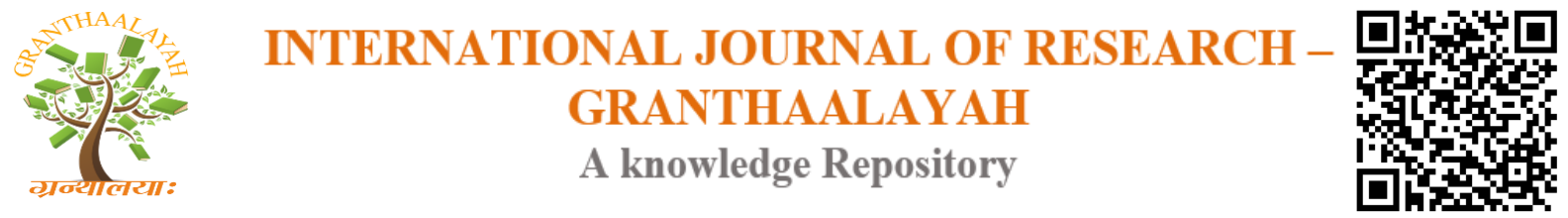

Management

\title{
PERFORMANCE REVIEW OF BANKING OMBUDSMAN SCHEME: AN EFFECTIVE TOOL TO EMPOWER BANK'S CUSTOMERS
}

\author{
Rajdeep Singh *1 \\ ${ }^{* 1}$ Research Scholar, University School of Applied Management, Punjabi University, Patiala, \\ INDIA
}

DOI: https://doi.org/10.29121/granthaalayah.v4.i6.2016.2642

\section{ABSTRACT}

The purpose of introducing the New Economic Policy 1991 was to bring in increased effectiveness and efficiency in the service quality by bringing about more privatization and globalization. The introduction of the New Economic Policy led to an increase in the number of service providers in different sectors including the banking sector. Therefore there was enhanced need of safeguarding the interests of the customers in this sector. In order to ensure proper and high quality and proper service quality to banking customers a major initiative was undertaken by the RBI in the year 1995. This much needed initiative was the introduction of The Banking Ombudsman Scheme (BOS) in the year 1995. A revision of the scheme was done in the year 2006 to make it more effective. The present study is an endeavor to review the performance of the scheme from 2010-2015.

Keywords:

Banking Ombudsman Scheme, Banking, Economic Policy, Performance Review.

Cite This Article: Rajdeep Singh, "PERFORMANCE REVIEW OF BANKING OMBUDSMAN SCHEME: AN EFFECTIVE TOOL TO EMPOWER BANK'S CUSTOMERS” International Journal of Research - Granthaalayah, Vol. 4, No. 6 (2016): 92-99.

\section{INTRODUCTION}

The institution of banking offers opportunity for investors and channelizes the resources available for the growth and sustenance of trade, commerce and industry, and, hence, an efficient banking system is necessary for the growth of the national economy (Malyadiri \& Sirisha, 2011). Banking industry is a service sector industry where customer satisfaction is the most important pillar to sustain the stiff competition among the players. But there have been some studies where the customers of the banks were dissatisfied with the services provided (Colgate and Lang, 2001; Colgate and Norris, 2001; Gronhaug and Gilly, 1991; White and Yanamandram, 2004). (Haq and Muhammad, 2012) found that such instances of dissatisfaction among the customers was highest in the public sector banks. 
One of the important pillars that affect the customer's satisfaction of services provided by the banks is the efficiency of the grievance handling mechanism, the quality and efficiency of such mechanism determines the reputation and future growth of the bank.

Therefore, it is necessary that in order to be more competitive and sustain the banking industry some checks and balances should be introduced so as to reduce inefficiency and maladministration which in turn will enhance customer satisfaction. The Reserve Bank of India as the apex bank and the regulator has been actively engaged in the review, examination and evaluation of customer service rendered by banks (Sharma, 2012). The RBI is continuously trying and monitoring the banking sector so to make it more customer friendly. The major efforts of RBI in the past have been to empower the common person while strengthening the customerservice delivery systems in banks by engaging in a consultative process with them.

Hence The Banking Ombudsman Scheme, 1995 was notified by RBI on June 14, 1995 in terms of the powers conferred on the Bank by Section 35A of the Banking Regulation Act, 1949 to provide for a system of redressal of grievances against banks. The Scheme sought to establish a system of expeditious and inexpensive resolution of customer complaints. The Scheme is in operation since 1995 and has been revised during the years 2002 and 2006 . The Scheme is being executed by Banking Ombudsmen appointed by Reserve Bank at 15 centres covering the entire country.

This paper is an endeavour to review the Banking Ombudsman Scheme from 2010-2015 and to make suggestions to further improve the scheme for the benefit of the customers. The current research has the following objectives:

1) To compare the number of complaints received from various population groups in order to assess the coverage of the scheme.

2) To assess the service quality of various banks by comparing bank wise complaints received by OBOs.

3) To compare the office-wise position of disposal of complaints by OBOs.

4) To examine the efficiency of the scheme by analyzing the grievance resolving ratio of Banking Ombudsmen offices.

In order to fulfil the above mentioned objectives the requisite data have been collected from RBI website and compiled from annual reports of banking ombudsmen scheme. Percentage analysis has been used to assess the data and get suitable insights.

\section{POPULATION GROUP-WISE ANALYSIS OF COMPLAINTS}

In an attempt to analyse the coverage of The Banking Ombudsmen Scheme a comparison of complaints received by the OBO's was done on the basis of population group to which the complainant belonged. Table 1 shows the population group wise number of complaints received from 2010-11 to 2014-15. 
Table 1: Population Group Wise Number of Complaints

\begin{tabular}{|l|l|l|l|l|l|}
\hline \multirow{2}{*}{ Sector } & \multicolumn{5}{|l|}{ Number of Complaints Received } \\
\cline { 2 - 6 } & $\mathbf{2 0 1 0 - 1 1}$ & $\mathbf{2 0 1 1 - 1 2}$ & $\mathbf{2 0 1 2 - 1 3}$ & $\mathbf{2 0 1 3 - 1 4}$ & $\mathbf{2 0 1 4 - 1 5}$ \\
\hline Rural & $7816(11 \%)$ & $8190(11 \%)$ & $8598(12 \%)$ & $9927(13 \%)$ & $11484(13 \%)$ \\
\hline $\begin{array}{l}\text { Semi } \\
\text { Urban }\end{array}$ & $10816(15 \%)$ & $11982(16 \%)$ & $10868(16 \%)$ & $12314(16 \%)$ & $13363(16 \%)$ \\
\hline Urban & $21218(30 \%)$ & $24565(34 \%)$ & $24246(34 \%)$ & $25448(33 \%)$ & $30710(36 \%)$ \\
\hline $\begin{array}{l}\text { Metropolit } \\
\text { an }\end{array}$ & $31424(44 \%)$ & $28152(39 \%)$ & $26829(38 \%)$ & $28884(38 \%)$ & $29574(35 \%)$ \\
\hline Total & $\mathbf{7 1 2 7 4}$ & $\mathbf{7 2 8 8 9}$ & $\mathbf{7 0 5 4 1}$ & $\mathbf{7 6 5 7 3}$ & $\mathbf{8 5 1 3 1}$ \\
\hline
\end{tabular}

Source: Compiled from Annual Reports of Banking Ombudsmen

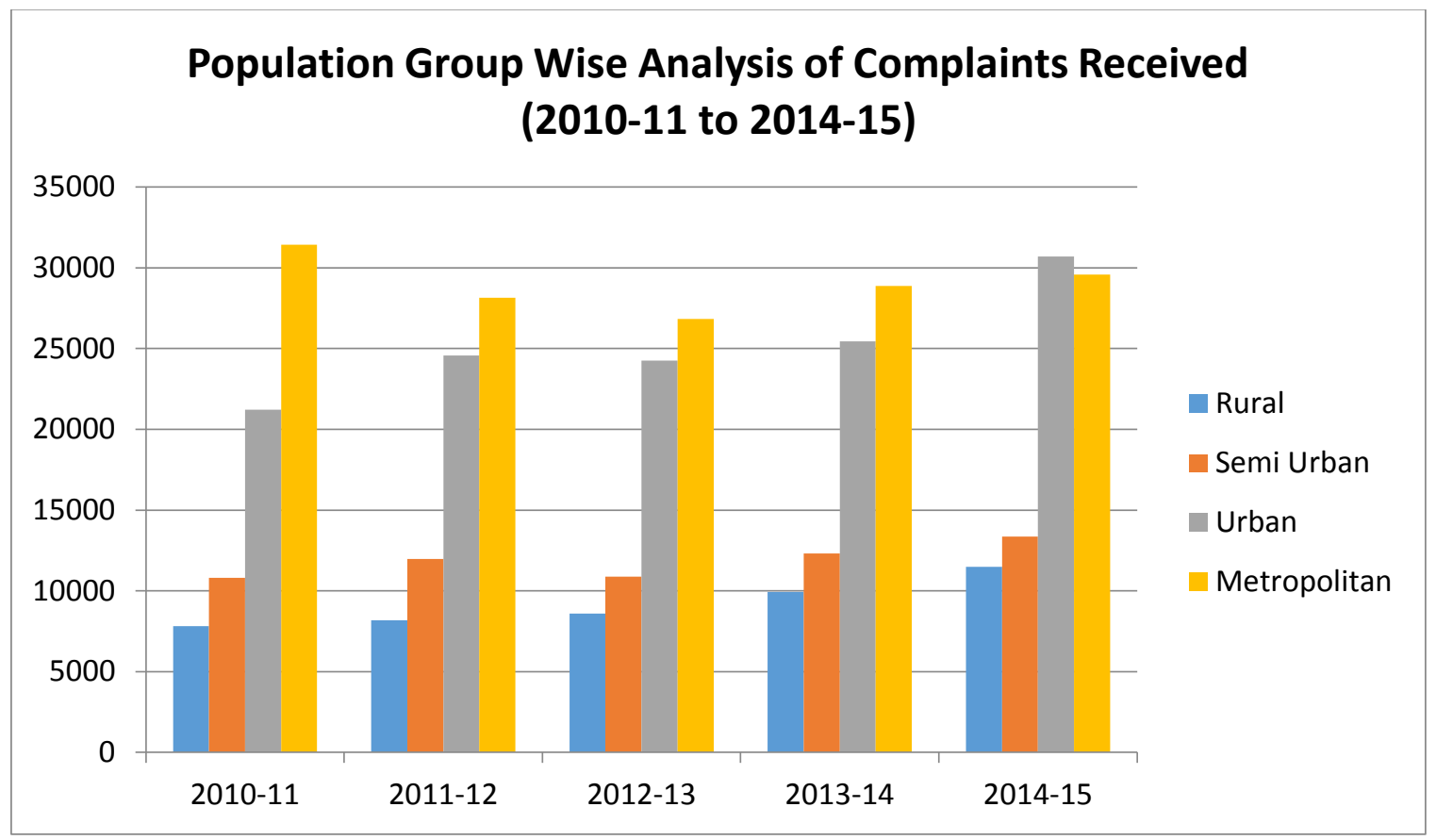

Source: Annual Reports of Banking Ombudsmen

Figure 1: Population Group Wise Analysis of Complaints Received

It may be observed from the above table and figure that there has been a medium change in the total number of complaints received by the OBOs from the year 2010-11 to 2014-15. There has been approximately $11 \%$ growth in the number of complaints during this period. However the population group wise analysis of complaints revealed that the source of complaints remained heavily skewed towards customers from metropolitan and urban areas. Complaints from urban and metro areas continued to account for more than $60 \%$ of the total complaints received during this 5 years period. In 2014-15 the share of complaints from urban and metropolitan areas stood at $71 \%$ and the remaining $29 \%$ was the share of complaints received from rural and semi urban areas. Hence, it can be concluded that the scheme has not covered the rural and the semi urban sector fully. There is a dire need to educate customers of rural sector about the grievance resolving mechanism provided by the Banking Ombudsmen Scheme. Rural sector persons are generally ignorant and are unaware about these systems which empower them. They generally 
ignore the mistakes and bad behaviour of bank staff. So they should be made aware and educated about the different complaint redressal system available to them and the process of filing complaints with BO offices.

\section{BANK GROUP WISE ANALYSIS OF COMPLAINTS}

The second objective was to compare the complaints received against various types of banks. Hence, Table 2 shows number of complaints received against various banks.

Table 2: Bank Group wise Number of Complaints

\begin{tabular}{|l|l|l|l|l|l|}
\hline \multirow{2}{*}{ Bank Group } & \multicolumn{5}{|l|}{ No of Complaints Received During } \\
\cline { 2 - 6 } & $\mathbf{2 0 1 0 - 1 1}$ & $\mathbf{2 0 1 1 - 1 2}$ & $\mathbf{2 0 1 2 - 1 3}$ & $\mathbf{2 0 1 3 - 1 4}$ & $\mathbf{2 0 1 4 - 1 5}$ \\
\hline Nationalized Banks & $20417(29 \%)$ & $22326(31 \%)$ & $21609(31 \%)$ & $24391(32 \%)$ & $28891(34 \%)$ \\
\hline SBI \& Associates & $22307(31 \%)$ & $25848(35 \%)$ & $23134(33 \%)$ & $24367(32 \%)$ & $26529(31 \%)$ \\
\hline Private Sector Banks & $17122(24 \%)$ & $15090(21 \%)$ & $15653(22 \%)$ & $17030(22 \%)$ & $19773(23 \%)$ \\
\hline Foreign Banks & $7081(10 \%)$ & $5068(7 \%)$ & $4859(7 \%)$ & $5016(7 \%)$ & $3406(4 \%)$ \\
\hline $\begin{array}{l}\text { RRBs/ Scheduled } \\
\text { Primary Urban Co- } \\
\text { op. Banks }\end{array}$ & $1130(2 \%)$ & $1439(2 \%)$ & $1489(2 \%)$ & $1590(2 \%)$ & $1966(2.30 \%)$ \\
\hline Others & & & & \\
\hline Total & $3217(4 \%)$ & $3118(4 \%)$ & $3797(5 \%)$ & $4179(5 \%)$ & $4566(5.70 \%)$ \\
\hline
\end{tabular}

Source: Compiled from Annual Reports of Banking Ombudsmen

It may be seen from the above table that in 2014-15 the highest number of complaints (34\%) were received against nationalized banks followed by SBI group (31\%), Private Sector banks (23\%) and foreign banks (4\%). Compared to 2010-11, there has been an increase in the proportion of complaints against nationalized banks by $41.5 \%$ which means that their service quality has declined or the customer's have become more empowered and aware about their rights. Complaints against SBI \& Associates stood at $31 \%$ only. Complaints against public sector banks and SBI group are large in number as compared to private and foreign banks which means that they should work more in the direction of customer satisfaction. In other words it can be depicted that service quality of private and foreign banks is much better than the public sector banks. Hence, public sector banks and SBI group should try to improve their service quality so as to satisfy their customers and sustain competition.

\section{COMPARISON OF OFFICE-WISE POSITION OF DISPOSAL OF COMPLAINTS BY OBOS}

The aim of the current objective is to assess and compare the office-wise position of disposal of complaints by OBOs. In order to do this rate of disposal of complaints by different offices all over the India has been calculated using the following equation.

$$
\text { Rate of Disposal }=\frac{\text { Complaints Disposed }}{\text { Complaints Handled }} * 100
$$


Table 3: BO office wise position of complaints disposed during 2014-15

\begin{tabular}{|l|l|l|l|l|l|l|}
\hline & $\begin{array}{l}\text { Complaints } \\
\text { pending at the } \\
\text { beginning of } \\
\text { the Year }\end{array}$ & $\begin{array}{l}\text { Complaints } \\
\text { Received } \\
\text { during the } \\
\text { Year }\end{array}$ & $\begin{array}{l}\text { Complai } \\
\text { nts } \\
\text { handled }\end{array}$ & $\begin{array}{l}\text { Complain } \\
\text { ts } \\
\text { Disposed }\end{array}$ & $\begin{array}{l}\text { Pendin } \\
\text { g at the } \\
\text { end of } \\
\text { the year }\end{array}$ & $\begin{array}{l}\text { Rate of } \\
\text { Disposa } \\
\text { ( \%) }\end{array}$ \\
\hline Ahmedabad & 54 & 4965 & 5019 & 5019 & 0 & 100 \\
\hline Bangalore & 158 & 4610 & 4768 & 4594 & 174 & 96.4 \\
\hline Bhopal & 243 & 5451 & 5694 & 4616 & 1078 & 81.1 \\
\hline Bhubaneswar & 14 & 2448 & 2462 & 2456 & 6 & 99.8 \\
\hline Chandigarh & 220 & 3131 & 3351 & 3288 & 63 & 98.1 \\
\hline Chennai & 241 & 8285 & 8526 & 8439 & 87 & 99 \\
\hline Guwahati & 39 & 1054 & 1093 & 1077 & 16 & 98.5 \\
\hline Hyderabad & 242 & 4366 & 4608 & 4486 & 122 & 97.4 \\
\hline Jaipur & 50 & 4088 & 4138 & 4133 & 5 & 99.9 \\
\hline Kanpur & 449 & 8818 & 9267 & 8678 & 589 & 93.6 \\
\hline Kolkata & 158 & 5277 & 5435 & 5364 & 71 & 98.7 \\
\hline Mumbai & 575 & 10446 & 11021 & 10619 & 402 & 96.4 \\
\hline New Delhi & 656 & 14712 & 15368 & 14436 & 932 & 93.9 \\
\hline Patna & 75 & 4456 & 4531 & 4406 & 125 & 97.2 \\
\hline $\begin{array}{l}\text { Thiruvananthapur } \\
\text { am }\end{array}$ & 133 & 3024 & 3157 & 3049 & 108 & 96.6 \\
\hline Total & $\mathbf{3 3 0 7}$ & $\mathbf{8 5 1 3 1}$ & $\mathbf{8 8 4 3 8}$ & $\mathbf{8 4 6 6 0}$ & $\mathbf{3 7 7 8}$ & $\mathbf{9 6}$ \\
\hline
\end{tabular}

Source: Compiled from Annual Reports of Banking Ombudsmen

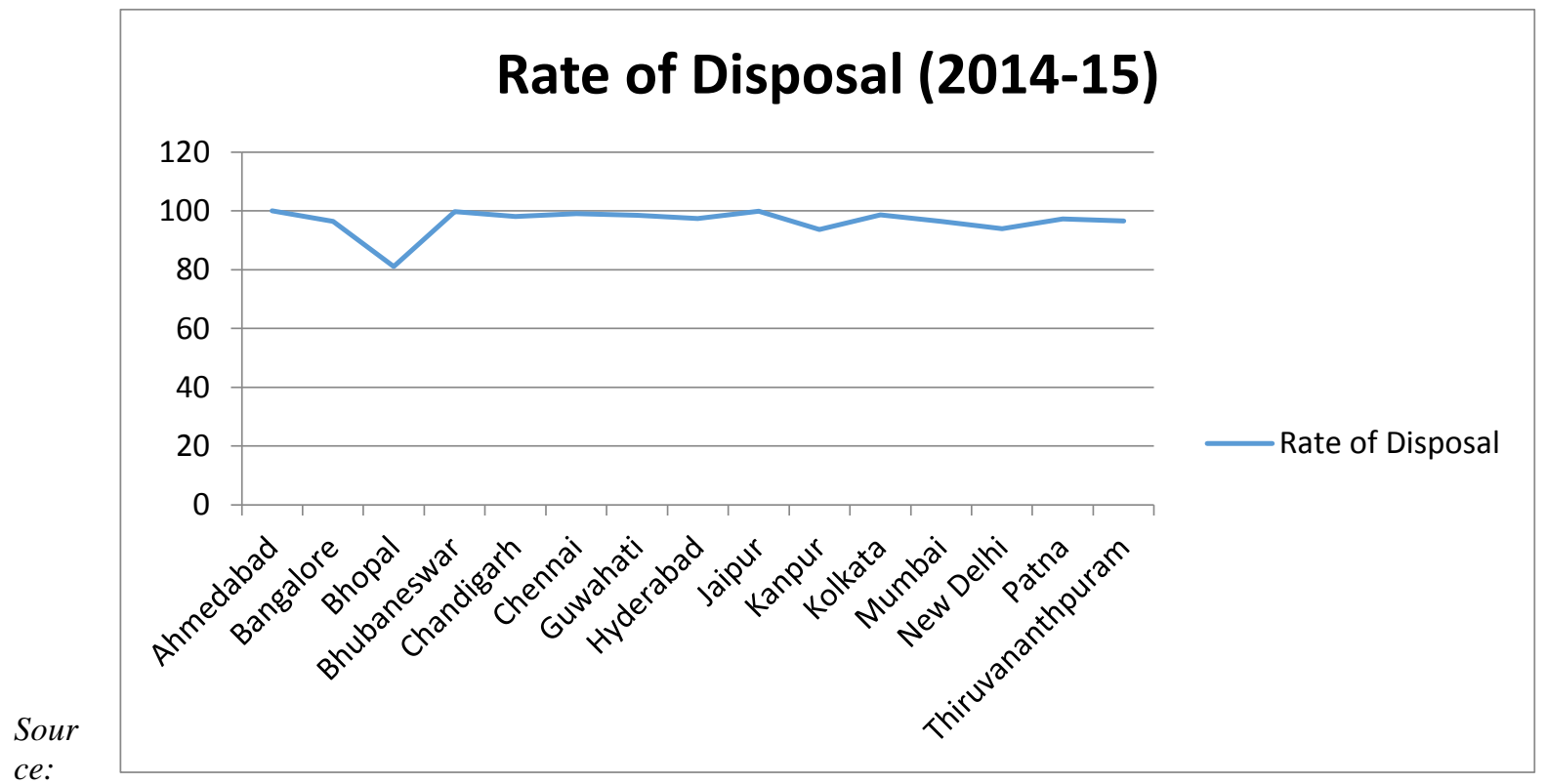

Annual Report of Banking Ombudsmen 2014-15

Figure 3: Office-Wise Rate of Disposal of Complaints for the year 2014-15

From the above table and figure it is clear that out of the 15 offices of Banking Ombudsmen all the offices have a good rate of disposal. The rate of disposal is highest for the Ahmedabad office 
standing at $100 \%$ followed by Jaipur at $99.9 \%$. The lowest rate of disposal of complaints is at Bhopal office which stood at $81.1 \%$. The offices where the rate of disposal of complaints is towards a lower side should put in more efforts and reach the average rate of disposal of complaints of all the offices.

\section{EXAMINING THE EFFICIENCY OF REVISED BANKING OMBUDSMEN SCHEME}

Banking Ombudsmen scheme was framed to improve the service efficiency of commercial banks. This scheme empowers the customers as they can file their complaints with the BO offices against commercial banks. But whether this scheme is efficient enough? Or whether customers' complaints are handled efficiently? Hence, an effort was made in the study to examine the efficiency of banking ombudsmen scheme. Here, grievance resolving ratio was calculated to check out that how many complaints are handled and how many are left unresolved. To check out the efficiency of the scheme, grievance resolving ratio has been calculated with the help of following formula:

Grievance Resolving Ratio $=\frac{\text { Complaints disposed off during the year }}{\text { Complaints received during the year }+ \text { Complaints brought forward }} * 100$

Table 4: Grievance Resolving Ratio of BOS

\begin{tabular}{|c|c|c|c|c|c|}
\hline \multirow{2}{*}{$\begin{array}{l}\text { Number of } \\
\text { Complaints }\end{array}$} & \multicolumn{5}{|l|}{ Year } \\
\hline & $2010-11$ & 2011-12 & 2012-13 & 2013-14 & 2014-15 \\
\hline $\begin{array}{l}\text { Received } \\
\text { during the } \\
\text { year }\end{array}$ & 71274 & 72889 & 70541 & 76573 & 85131 \\
\hline $\begin{array}{l}\text { Brought } \\
\text { forward from } \\
\text { previous year }\end{array}$ & 5364 & 4618 & 4642 & 5479 & 3307 \\
\hline $\begin{array}{l}\text { Disposed of } \\
\text { during the } \\
\text { year }\end{array}$ & 72,020 & 72865 & 69704 & 78745 & 84660 \\
\hline $\begin{array}{l}\text { Grievance } \\
\text { Resolving } \\
\text { Ratio }\end{array}$ & $94 \%$ & $94 \%$ & $93 \%$ & $96 \%$ & $96 \%$ \\
\hline $\begin{array}{l}\text { Carried } \\
\text { forward to the } \\
\text { next year }\end{array}$ & 4618 & 4642 & 5479 & 3307 & 3778 \\
\hline
\end{tabular}

Source:Compiled from Annual Reports of Banking Ombudsmen 


\section{Grievance Resolving Ratio (2010-11 to 2014-15)}

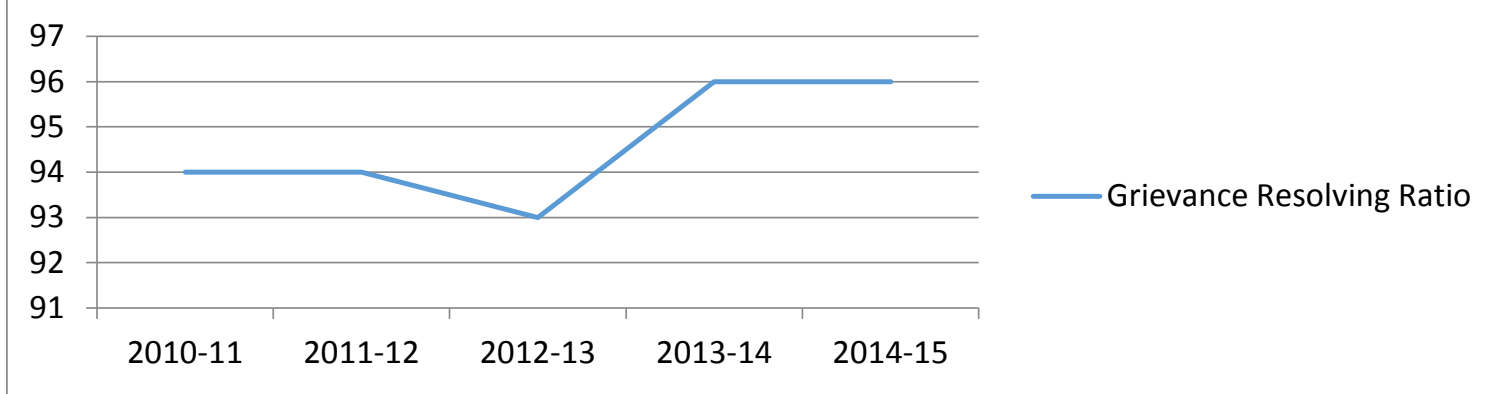

Source: Annual Reports of Banking Ombudsmen

Figure 4: Grievance Resolving Ratio of Banking Ombudsmen Offices post 2006

In an endeavour to assess the efficiency of the revised Banking Ombudsmen Scheme grievance resolving ratio was calculated using the methodology used by (Manpreet, 2014). Looking at the grievance resolving ratio it can be concluded that the revised scheme is very efficient and is on a continuous path of improvement as the grievance resolving ratio has increased from $94 \%$ in 2010-11 to $96 \%$ in 2014-15. Therefore, the revised scheme has truly empowered the customers in banking industry and is fully able to handle the grievances of the customers.

\section{CONCLUSION AND SUGGESTIONS}

In order to assess the efficiency of the revised Banking Ombudsman Scheme we have carried out an analysis of the sector wise complaints received, bank group wise analysis of complaints received, office wise position of disposal of complaints and at the last the grievance resolving ratio from the year 2010-11 to 2014-15.

An analysis of the sector wise complaints, it was found that rural sector is not active like the urban and semi urban sectors. The major reasons for this trend are the lack of awareness and ability among the rural sector population to file complaints against the bank's misdeeds. There is a strong need to aware the rural population about the existence of grievance resolving mechanism and educate them about complaint filing procedure through Banking Ombudsmen Scheme.

Reviewing the bank wise complaints showed that complaints against public sector banks and SBI group are large in number as compared to private and foreign banks which means that they should work more in the direction of customer satisfaction. In other words it can be depicted that service quality of private and foreign banks is much better than the public sector banks. Hence, public sector banks and SBI group should try to improve their service quality so as to satisfy their customers and sustain competition.

Assessing the office wise position of disposal of complaints revealed that out of the 15 offices of Banking Ombudsmen all the offices have a good rate of disposal. The rate of disposal is highest for the Ahmedabad office standing at $100 \%$ followed by Jaipur at $99.9 \%$. The lowest rate of disposal of complaints is at Bhopal office which stood at $81.1 \%$. The offices where the rate of 
disposal of complaints is towards a lower side should put in more efforts and reach the average rate of disposal of complaints of all the offices.

Looking at the grievance resolving ratio it can be concluded that the revised scheme is very efficient and is on a continuous path of improvement as the grievance resolving ratio has increased from $94 \%$ in 2010-11 to $96 \%$ in 2014-15. Therefore, the revised scheme has truly empowered the customers in banking industry and is fully able to handle the grievances of the customers.

According to (Perry, Ganey and Hall, 1997) there are only $11 \%$ of the dissatisfied customers that make a formal complaint against their banks. Hence, introduction and implementation of the Banking Ombudsman Scheme is only the first step to empower customers. There is an urgent need to promote this scheme by making the people aware about this scheme and educating them about the complaint filing procedure through this scheme. The major focus of the education program for the scheme should be on the rural population. After the implementation of the Jan Dhan Yojana scheme by the Government of India there is a stronger need to take this scheme to the grassroots level towards the customers who are economically backward as they are the ones who are most exploited by the misdeeds and maladministration of the banking staff.

\section{REFERENCES}

[1] Colgate, M. and Hedge, R. (2001), "An investigation into the switching process in retail banking services”, The International Journal of Bank Marketing, Vol. 19 No. 5, pp. 201 12.

[2] Colgate, M. and Lang, B. (2001), "Switching barriers in consumer markets: an investigation of the financial services industry", Journal of Consumer Marketing, Vol. 18 No. 4, pp. 33247.

[3] Gronhaug, K. and Gilly, M. (1991), "A transaction cost approach to consumer dissatisfaction and complaint actions”, Journal of Economic Psychology, Vol. 12 No.1, pp. 165-83.

[4] Haq, W. And Muhammad (2012), "Customer Satisfaction: A Comparison of Public and Private Banks of Pakistan”, IOSR Journal of Business and Management, Vol. 1 (5), pp. 1-6.

[5] India, R. B. (2006-07). The Banking Ombudsman Scheme . RBI.

[6] Kaur, D. M. (2015). Empowerment of Banks' Customers through Grievance Resolving Mechanism: A Review of Banking Ombudsmen Scheme. Contemporary Issues in Management. Fatehgarh Sahib.

[7] Malyadri, P., \& Sirisha, S. (2012). Success of banking ombudsmen scheme: Myth or reality. International Journal of Research Studies in Management, 17-24.

[8] Press, I., Ganey, R. And Hall, M. (1997), "What is most important to customer satisfaction?"

[9] ABA Banking Journal, Vol. 89 (9), p. 73-75.

[10] Sharma, I. (2012). Banking Ombudsman: A New Way To Face Banking Redressal Challenges. Academia , 188-199.

[11] White, L. and Yanamandram, V. (2004), "Why customers stay: reasons and consequences of inertia in financial services”, Managing Service Quality, Vol. 14 No. 2/3, pp. 183-194. 